\title{
RELASI BUDAYA \\ DALAM PENYEBARAN ISLAM DI BUMI WALI TUBAN
}

\author{
Jamal Ghofir \\ Email : kaos_legend@yahoo.co.id
}

Tuban As a coastal area has become an important area for all the development of the archipelago's culture. This is partly due to the location of Tuban as a large port in the northern coastal area which is the main route for the entry of all outside cultures in the interior. So that the process of the spread of culture, especially Islam (Middle East), is in Indonesia, so the city of Tuban becomes important to study as the location of the beginning of the cultural scene.

Keywords: Relationship, Islam, Culture, City of Tuban.

*Jamal Ghofir adalah Ketua LP3M dan Dosen Prodi PAI Sekolah Tinggi Ilmu Tarbiyah Makhdum Ibrahim Tuban

\section{A. Pendahuluan}

Kehadiran Islam di Indonesia telah cukup banyak mendapat perhatian dan telaah para pemikir dan sejarawan dari berbagai kalangan. Berbagai pendapat dan teori yang membincang persoalan tersebut membuktikan bahwa tema Islam memang menarik untuk dikaji terlebih di negeri yang dikenal mayoritas penduduknya muslim. Maka tak berlebihan, studi mengenai latar historis dan proses perkembangan selanjutnya dari agama ini. Sehingga Islam memperoleh tempat dan mampu mengikat begitu banyak pengikut di wilayah ini, serta cukup punya nilai guna memahami dan memaknai lebih dalam dinamika keberagamaan Islam dalam konteks kontemporer di Indonesia.

Diskusi mengenai kedatangan Islam di Indonesia sejauh ini berkisar pada tiga tema utama, yaitu: tempat asal kedatangannya, para pembawanya, dan waktu 
kedatangannya. Hal lain yang juga patut diperhatikan adalah dimensi proses dari interaksi awal dan lanjutan antara Islam dan penduduk lokal berikut konstruk kepercayaan atau agama yang telah ada sebelumnya.

Tuban Seabagai daerah pesisir telah menjadi daerah yang penting bagi seluruh perkembangan kebudayaan Nusantara. Hal ini salah satunya disebabkan oleh lokasi Tuban sebagai pelabuhan besar di daerah pesisir utara yang merupakan jalur utama masuknya seluruh kebudayaan luar ke pedalaman. Sehingga proses persebaran kebudayaan, khususnya Islam (Timur Tengah), yang ada di Indonesia, maka kota Tuban menjadi penting untuk diteliti sebagai lokasi awal perseberan kebudayaan.

Kota menjadi media yang sangat menarik digunakan dalam memahami atau mengkaji banyak permasalahan. Begitupun untuk kajian ini, kota ditempatkan sebagai teks yang harus dibaca dan selami untuk memahami realitas keagamaan yang terjadi, atau bisa juga sebaliknya " memperhatikan " realitas keagamaan dalam mencermati perkembangan kota.

Permasalahan pokok yang dikaji dalam penulisan ini, yaitu " dinamika persebaran keagamaan di Kota Tuban dalam kaitannya dengan penggunaan ruang keagamaan (religious space). Dalam proses analisis kemudian perlu melihat juga perkembangan Kota Tuban dan agama-agama lain yang berkembang, penyebaran agama terhadap perkembangan dan perubahan sosial masyarakat, dinamika keagamaan yang ikut mempengaruhi penggunaan ruang kota, terutama dengan pendirian rumah ibadah, dan mengapa kompromi begitu dominan dalam hubungan keagamaan di Tuban.

Fokus lain dari penulisan ini mencoba menyelidiki distribusi atas ruang dari “ Institusi Agama " di Kota Tuban. Hal ini penting karena ketika sedang berkonsentrasi pada daerah keagamaan maka sulit untuk melepaskan diri atas perhatian dan hubungannya dengan gagasan akan kepercayaan masyarakat pendukungnya termasuk kehidupan politik yang melingkupinya.

Konteks penulisan ini menekankan dua konsep utama yang dipakai yakni kota dan agama. Dalam sejarah umat manusia, keduanya mempunyai peranan 
penting atau bahkan menjadi kebutuhan utama. Keduanya muncul hampir bersamaan dengan kehadiran manusia, dan bahkan dapat dikatakan sama tuanya dengan peradaban manusia. Terpenting keduanya saling mendukung dan membutuhkan dalam berbagai zaman.

Kota pada dasarnya dipahami dengan begitu banyak arti, tergantung penggunaan perspektifnya. Aktivitas keagamaan dalam konteks suatu kota, Mayer menekankan kota dilihat sebagai tempat bermukim-nya penduduk. Baginya terpenting adalah penghuni yang menciptakan segalanya dalam kota, oleh karena itu untuk memahami kota, melihat manusia-nya menjadi faktor esensial. Berarti juga bahwa aktivitas penghuni kota adalah perhatian utama. Seperti juga paparan Lewis Mumford yang melihat kota sebagai "tempat pertemuan", kota seperti magnet yang semakin kuat tarikannya baik bagi perekonomian maupun keagamaan. Hal ini sejalan jika melihat kota sebagai lambang dalam perjalanan sejarahnya (Daldjoeni, 1998 : 37-38). Paul Wheatley mengatakan bahwa di masa awal peradaban umat manusia, pusat-pusat perkotaan tumbuh maju sebagai kompleks upacara keagamaan, di sana ada candi atau istana.

Kota-kota di Indonesia jelas tidak dapat dipisahkan dengan unsur agama (Daldjoeni, 1998 : 39). Pembangunan kota-kota di Jawa, selalu menyatu dengan makna religius-magis. Secara ruang, bangunan ibadah memiliki posisi strategis. Tuban dalam hal ini, meskipun dibangun dengan tidak menekankan unsur agama, namun Tuban harus menerima kenyataan dimana dinamika keagamaan cukup dominan berlangsung. Pada perkembangan lebih lanjut, agama mengambil tempat yang utama dalam masyarakat kota dan kotanya sendiri, termasuk penggunaan ruangnya.

Begitupun, defenisi agama demikian luas dan beragam, karenanya Max Weber menyatakan bahwa definisi itu akan jatuh di bagian akhir pembahasan (Weber, 1964 : 1). Tapi alangkah baiknya ada pengertian yang membantu sehubungan dengan kajian ini. Agama sebagai kajian ilmiah mulanya didefinisikan E.B. Tylor sebagai "kepercayaan terhadap adanya wujud-wujud spritual”. Kemudian Radcliffe-Brown menyatakan bahwa ekspresi suatu bentuk 
ketergantungan pada kekuatan di luar diri sendiri, yakni kekuatan yang dapat dikatakan sebagai kekuatan spritual atau kekuatan moral. Ekspresi penting dari rasa ketergantungan ini adalah peribadatan. Dia menekankan kepastian mengenai peribadatan dan kewajiban sosial untuk melaksanakannya (Scharf' 1995 : 30). Pengertian ini sejalan dengan pendapat Emile Durkheim yang menekankan ciri kolektif atau sosial pada agama dalam definisinya. Menurutnya agama adalah sistem yang menyatu mengenai berbagai kepercayaan dan peribadatan, kepercayaan-kepercayaan dan peribadatan-peribadatan yang mempersatukan semua orang yang menganutnya ke dalam suatu komunitas moral yang disebut gereja (Durkheim, 1964 : 40), dikutip oleh Betty R. Scharf, Kajian Sosiologi Agama (Yogyakarta: Tiara Wacana, 1995), hlm. 30.

Dari berbagai definisi kota dan agama tersebut, ada 'benang merah' yang menghubungkannya dengan kajian ini, yakni peribadatan dan ciri kolektif sosial agama. Hal itu berhubungan dengan aktivitas sosial yang memerlukan komunitas serta membutuhkan ruang dalam pelaksanaannya. Konsep ini bisa dimaknai dalam hal yang lebih jelas, seperti yang disebut Freek Colombijn, bahwa agama memiliki ritual untuk peribadatan yang tentunya membutuhkan ruang (kota), juga mempunyai prosesi yang sepanjang tahun dirayakan yang harus diorganisir baik oleh lembaga agama maupun organisasi sosial keagamaan. Agama sebagai "peristiwa sosial", sebagai kekuatan yang sering memainkan peranan penting dalam realitas dan dinamika sosial, khususnya dalam konteks kota. Dalam berbagai kasus, kota menjadi hidup dengan berbagai aktivitas keagamaan atau bahkan karakter dan ciri kota terbentuk karena agama atau kepentingan agama (Colombijn, 1994 : 314).

Singkatnya bahwa melihat kota sebagai sistem sosial dengan menjelaskan perkembangan agama sebagai peristiwa sosial. Tapi dalam pembahasan yang lebih kompleks, instrumen lain pada masyarakat yang terus berkembang dan berpengaruh, seperti halnya politik atau kekuasaan, kepentingan ekonomi, interaksi sosial, dan sebagainya. Kota menjadi tempat berkembang agama, kota merespon dinamika keagamaan yang berlangsung, bahkan tipikal kota-kota tertentu sangat dipengaruhi oleh aspek keagamaan. Kehidupan religius yang 
terorganisir dalam konteks kota memerlukan tempat atau ruang-ruang untuk melaksanakan ritual bersama (Wiryomartono, 1995 : 8). Untuk Tuban, perkembangan agama khususnya pascakolonial ditandai dengan meningkatnya aktivitas keagamaan, pada akhirnya memberi pengaruh yang kuat atas fisik kota. Tidak dapat dipungkiri banyak simbol agama dalam bentuk bangunan kemudian muncul.

Perkembangan kota pada dasarnya tidak lain adalah penggunaan ruang secara terus menerus. Berbagai bangunan keagamaan tadi tidak dapat terpisahkan penggunaannya secara simbolik. Secara umum simbol dapat dipahami sebagai sesuatu yang menceritakan sesuatu. Freek Colombijn mendefinisikan simbol sebagai sebuah perwujudan dengan makna tertentu yang dilekatkan padanya. Sifat-sifat dari perwujudan tersebut berhubungan dengan pengalaman-pengalaman keseharian yang berada di luar perwujudan itu sendiri. Lebih spesifik Ahimsa mengartikan bahwa simbol adalah segala sesuatu yang dimaknai, sesuatu menjadi berarti jika diberi makna (Putra, 2002: Ceramah Kebudayaan).

Menurut Colombijn dalam pengamatan terhadap simbol, ia membedakan antara simbol yang diciptakan secara sadar dan simbol berkembang lamakelamaan. Simbol yang diciptakan dengan sadar akan mudah diketahui dan ditelusuri; siapa pemrakarsanya. Dari sini akan tergambar siapa yang mendominasi kota dan apakah mereka juga mendominasi simbol atau sebaliknya, akan tergambar pula pikiran penguasa, termasuk apakah masih ada ruang untuk menentang kehadiran simbol yang ada. Simbol yang berkembang lama-kelamaan merupakan proses waktu yang menyebabkan 'sesuatu' menjadi identik dengan kota yang bersangkutan. Tuban mempunyai kecenderungan ini, kota yang berkembang dengan bangunan keagamaan yang lama-kelamaan identik dengan kota. Namun yang terpenting dari keduanya adalah selalu siapa yang menguasai kota, bukan saja kuasa dalam kehidupan sehari-hari tapi juga kuasa dalam pikiran dan persepsi masyarakat.

Tidak ada pendekatan yang mutlak yang dapat dipakai dalam memahami kota-kota di Indonesia, karena masing-masing kota tumbuh atas kekhasannya sendiri. Akan tetapi jika melihat kota kolonial, ada persamaan dalam banyak hal. 
Secara umum dapat dikatakan bahwa kota masa kolonial adalah representasi dari simbol kolonial itu sendiri, repsentasi dari pusat pemerintahan dan ekonomi, serta representasi kekuasaan yang diskriminatif. Kota kolonial tidak dapat dipisahkan dengan kebijakan pemberlakuan garis warna (colour line) yakni pemisahan berdasarkan warna kulit, diskriminasi ras yang mencolok seperti adanya Segregasi dengan pemisahan pemukiman, pemakaian bahasa, pekerjaan, subordinasi, eksploitasi, dan sebagainya.

\section{B. Relasi Budaya dan Perkembangan Islam}

Studi dan penelitian masalah pertemuan antar kebudayaan merupakan suatu kegiatan yang relatif lama dalam disiplin antropologi. Hal ini disebabkan oleh semakin bertambahnya kegiatan penyelidikan kontak kebudayaan pada beberapa abad terakhir ini. Hal itu menghasilkan berbagai kenyataan bahwa semua masyarakat dan kebudayaan yang hidup di dunia ini selalu bergerak, berubah dan berkembang. Demikian pula, banyak data dari kumpulan kitab etnografi sudah tidak sesuai dengan keadaan masa kini. Dengan intensifnya pengaruh penyebaran unsur-unsur kebudayaan di seluruh penjuru dunia pada abad-abad sembilan belas dan dua puluhan ini menyebabkan kian menghilangnya bentuk-bentuk masyarakat primitif dan terasing.

Sekalipun begitu, perkembangan suatu peradaban manusia sangat sulit untuk lepas dari perekembangan kebudayaan masyarakat yang lain. Hal ini bisa dilihat dari peninggalan-peninggalan budaya baik artefak, prasasti maupun dokumen-dokumen yang menunjukkan interaksi dengan masyarakat di luar kebudayaan setempat. Penyelidikan-penyelidikan para antropolog terhadap adanya gejala persamaan unsur-unsur kebudayaan yang satu dengan kebudayaan yang lain, kendatipun letaknya berjauhan merupakan fondasi dasar dari teori difusi kebudayaan.

Sejak lama para sarjana tertarik akan adanya bentuk-bentuk yang sama dari unsur-unsur kebudayaan di berbagai tempat yang seringkali jauh letaknya satu sama lain. Ketika cara cara berfikir mengenai evolusi kebudayaan berkuasa, para sarjana menguraikan gejala persamaan aitu dengan keterangan bahwa 
persaman-persamaan itu disebabkan karena tingkat-tingkat yang sama dalam proses evolusi kebudayaan di berbagai tempat di muka bumi ini (Koentjaraningrat, 2007 : 110).

Terdapat dua pendapat tentang gejala persamaan unsur kebudayaan yang ada di muka bumi ini. Pendapat pertama mengatakan bahwa persamaanpersamaan unsur kebudayaan itu terjadi, karena tingkatan yang sama dalam proses evolusi dalam kebudayaannya rnasing-masing. Pendapat kedua muncul di kalangan ilmu antropologi yang berpandangan bahwa gejala persamaan-persamaan itu, akibat adanya persebaran atau difusi unsur kebudayaan dari satu tempat ke tempat lainnya.

Hasil dari kontak kebudayaan tersebut terjadi dari beragam aktifitas ekonomis maupun politik. Sudah menjadi hukum peradaban, di mana suatu kebudayaan yang maju akan mempengaruhi kebudayaan lain untuk menirunya. Walaupun begitu kebudayaan setempat tidak serta merta hilang begitu saja, artinya pertemuan dua kebudayaan tersebut kemudian melahirkan akulturasi budaya.

Akulturasi akan terjadi apabila terdapat dua kebudayaan atau lebih yang berbeda sama sekali (asing dan asli) berpadu sehingga proses-proses ataupun penebaran unsur-unsur kebudayaan asing secara lambat laun diolah sedemikian rupa ke dalam kebudayaan asli dengan tidak menghilangkan identitas maupun keasliannya. Misalnya, di dalam kehidupan masyarakat sehari-hari dijumpai bermacam-macam bentuk serta sistem politik (demokrasi), ekonomi (koperasi), edukasi (perguruan tinggi), agama dan kepercayaan lokal, dan lain-lain. Kalau dilihat sepintas lalu, kesemuanya itu seolah-olah merupakan unsur asli kebudayaan Indonesia, tetapi sesungguhnya aktivitas-aktivitas tersebut merupakan hasil pengintegrasian dan pengabsorsian dari bentuk-bentuk dan sistem-sistem yang telah lama berkembang di negara-negara Barat serta Timur Tengah.

Pada awal-awal studi akulturasi ini, banyak dihasilkan karangan hasil penelitian yang masih bersifat deskriptif (Koentjaraningrat, 2007 : 92), dalam arti bahwa tulisan-tulisan itu hanya merupakan pelukisan proses-proses pertemuan kebudayaan di suatu masyarakat daerah tertentu. Di antaranya ialah karangan-- 
karangan dari E.W. Giffort di Kepulauan Tonga (1924); R. Redfield di negara Meksiko (1929); D.N. Majumbar di negara India (1937); M. Hunter Wilson di daerah Afrika Selatan (1936); Sol Tax di wilayah negara Guatemala (1938), dan H.I. Hogbin di Kepulauan Solomon (1939). Baru beberapa tahun kemudian ada tulisan-tulisan hasil penelitian akulturasi teoretis, seperti yang ditulis oleh G.HF. Pitts Rivers (1926); R. Turnwald (1932); M. Hunter Wilson (1934); GH. Wagner (1936), dan sebagainya (Koentjaraningrat : 1972).

Semua studi dan penelitian tersebut di atas hampir seluruhnya berpusat kepada proses-proses perpaduan dan pengaruh kebudayaan Barat terhadap masyarakat dan kebudayaan di luar Eropa-Amerika. Baru sesudah beberapa waktu berselang, ada aktivitas-aktivitas penelitian dan penulisan akulturasi yang terjadi di dalam dan di antara kebudayaan-kebudayaan setempat dari berbagai wilayah, seperti R.B. Eikwall di negara Tibet (1939); J. Greenberg di daerah Sudan Barat (1941); serta E.J. Lindgern di wilayah Siberia (1983).

Dalam peristiwa kontak kebudayaan atau akulturasi ini seringkali terjadi perubahan dan perkembangan kebudayaan pada masyarakat setempat, yang prosesnya dapat menimbulkan sejumlah masalah, baik yang berpengaruh positif maupun negatif.

Adapun masalah-masalah tersebut adalah :

a. Adisi (addition) ialah penambahan unsur-unsur kebudayaan yang lama oleh kompleksnya unsur-unsur kebudayaan yang baru sehingga timbul perubahan struktural atau tidak sama sekali.

b. Sinkretisme ialah perpaduan antara unsur-unsur kebudayaan yang lama dengan kompleksnya unsur-unsur kebudayaan yang baru dengan tidak meninggalkan jati diri masing-masing dan membentuk sistem kebudayaan baru.

c. Substitusi (substitution) ialah unsur-unsur kebudayaan yang ada atau yang terdahulu diganti oleh kompleks unsur-unsur kebudayaan yang baru, terutama yang dapat memenuhi fung- 
sinya. Dalam hal ini, kemungkinan akan terjadi perubahan struktural sangat kecil.

d. Dekulturasi (deculturation) ialah tumbuhnya unsur-unsur kebudayaan yang baru untuk memenuhi berbagai kebutuhan baru yang timbul kerena perubahan situasi.

e. Rejeksi (Rejection) ialah penolakan unsur-unsur perubahan yang terjadi amat cepat sehingga sejumlah besar orang tidak dapat menerimanya. Hal ini dapat menimbulkan penolakan sama sekali, bahkan pemberontakan atau gerakan kebangkitan (Haviland, 1988).

Hasil dari berbagai proses akulturasi tersebut dapat menimbulkan perubahan kebudayaan. Dalam hal ini ada dua peristiwa perubahan kebudayaan yaitu yang terjadi secara paksa dan yang berlangsung secara damai. Seorang antropologi yang juga tertarik dengan masalah-masalah akulturasi R. Linton, ia mempunyai suatu pendirian mengenai masalah unsur-unsur kebudayaan yang mudah berubah dan yang sukar berubah bila dihadapkan dengan pengaruh asing. Ia mengemukakan sebuah konsep bawhasanya perbedaan antara (cover culture) dan (over culture) memiliki inti : 1. Sistem nilai-nilai budaya, 2. keyakinankeyakinan keagaman yang dianggap keramat, 3. Beberapa adat yang sudah dipelajari sanggat dini dalam proses sosialisasi individu warga masyarakat, 4. Beberapa adat yang mempunyai fungsi yang terjaring luasa dalam masyarakat. Sedangkan bagian lahir dari suatu kebudayaan misalnya kebudayaan fisik yang meliputi alat atau benda yang berguna, ilmu pengetahuan, tata cara, gaya hidup dan rekreasi yang memiliki kegunaan dalam kenyamanan. Dan bagian yang lamban dalam perubahanya dan sulit untuk di gantin dengan unsur-unsur asing adalah bagian dari cover culture ((Koentjaraningrat, 2007 : 97).

Adapun perubahan kebudayaan secara paksa timbul melalui penaklukan dan pendudukan. Kejadian ini menyebabkan penghancuran kebudayaan (culture crash) dari masyarakat atau komunitas pribumi yang ditundukkan serta dikuasai. Dan kolonisasi ini muncul pergantian serta penambahan unsur-unsur kebudayaan 
baru yang berasal dari para panjajah, seperti tumbuhnya sistem-sistem organisasi sosial, perekonomian, teknologi, sistem religi, dan beragam bentuk kesenian baru.

Kasus-kasus perubahan kebudayaan yang ekstrim dari kolonisasi di atas ialah berupa penguasaan sistem politik dan militer yang menyebabkan penduduk pribumi tidak berdaya mempertahankan unsur-unsur umum kebudayaan asli atau kebudayaan tradisional mereka.

Proses penelitian akulturasi perlu diteliti secara analitis dan sistematis. Untuk itu perlu dilakukan hal-hal sebagai berikut; (a). Pencatatan dan pengumpulan sumber-sumber keterangan keadaan masyarakat di tempat sebelum mengalami kontak dengan orang maupun kebudayaan asing. (b) Penelitian penyiar atau pembawa unsur-unsur kebudayaan asing ke masyarakatan daerah, apakah mereka itu berasal dari golongan musafir, pelaut, penyebar agama, penyelidik alam, pegawai pemerintahan jajahan, ataukah dari golongan cendekiawan, dan lain-lain, (mereka dapat disebut agens of acculturation). (c) Perunutan saluran-saluran manakah yang dilalui oleh unsur-unsur kebudayaan asing. (d) Penyelidikan bagian-bagian lapisan masyarakat manakah yang pertama kali terkena pengaruh unsur-unsur kebudayaan luar. (e) Penganalisisan reaksireaksi yang timbul dari warga masyarakat daerah yang terpengaruh oleh unsurunsur kebudayaan baru.

\section{Perkembangan Islam di Bumi Wali Tuban}

Tuban disebut sebagai salah satu kota pelabuhan utama di pantai Utara Jawa yang kaya dan banyak penduduk Tionghoanya. Orang Cina menyebut Tuban dengan nama Duban atau nama lainnya adalah Chumin. Pasukan Cina-Mongolia (tentara Tatar), yang pada th. 1292 datang menyerang Jawa bagian Timur (kejadian yang menyebabkan berdirinya kerajaan Majapahit) mendarat di pantai Tuban. Dari sana pulalah sisa-sisa tentaranya kemudian meninggalkan Pulau Jawa untuk kembali ke negaranya (Graaf, 1985:164). Tapi sejak abad ke 15 dan 16 kapal-kapal dagang yang berukuran sedang saja sudah terpaksa membuang sauh di laut yang cukup jauh dari garis pantai. Sesudah abad ke 16 itu memang pantai Tuban menjadi dangkal oleh endapan lumpur. Keadaan geografis seperti ini membuat kota Tuban dalam perjalanan sejarah selanjutnya sudah tidak menjadi 
kota pelabuhan yang penting lagi (Graaf, 1985:163). Berkenaan dengan kejayaan Tuban sebagai pelabuhan terbesar telah di jelaskan oleh Pramoedya Ananta Toer dalam karyanya yang berjudul “Arus Balik” Sebuah Epos Pasca Kejayaan Nusantara di Awal Abad 16 tertulis bahwa "Bandar Tuban adalah bikinan alam yang pemurah, disempurnakan oleh tangan manusia selama paling tidak seribu tahun. Lautnya dalam dan dermaganya kokoh, indah juga bikinan alam, sepotong jalur karang yang menjorok ke laut. Pedagang-pedagang atas angin menamai Bandar ini Permata Bumi Selatan" (Toer, 2002 : 20).

Untuk mengurangi kesimpang siuran tentang hari jadi kota Tuban Bupati Kepala Daerah Tingkat II Tuban (waktu itu dijabat Drs. Djoewahiri Martoprawiro), menetapkan tanggal 12 Nopember 1293 sebagai hari jadi kota Tuban. Panitia kecil yang dibentuk oleh Pemerintah Daerah Tingkat II Tuban waktu itu memberi alasan bahwa ditetapkannya tanggal tersebut karena bertepatan dengan diangkatnya Ronggolawe sebagai Adipati Tuban. Ronggolawe dianggap sebagai pahlawan bagi rakyat Tuban, dan dianggap sebagai Bupati pertama Tuban. Seperti halnya dengan kota-kota lain di Jawa pada umumnya sumber sejarah kota Tuban sangat sulit didapat. Bahan tulisan yang ada penuh dengan campuran antara sejarah dan legenda. Buku "Babad Tuban" yang ditulis oleh Tan Khoen Swie (1936) letaknya sumber air bersih tersebut (Sumur Srumbung) berjarak kurang lebih $10 \mathrm{~m}$ dekat pantai, tapi sumur (sumber air) tersebut tetap tawar dan segar. Sumber lain tentang sejarah dan legenda tentang kota Tuban lihat: Soeparmo, R. (1983), Tujuh Ratus Tahun Tuban, dan buku: Hari Jadi Tuban (1987), Pemerintah Kabupaten Daerah Tingkat II Tuban.

Tuban, yang kalau dilihat dari arah laut, seolah-olah seperti batu putih yang terapung (watu kambang putih dalam bahasa Jawa). Sumber ini didapat dari buku : Soeparmo, R. (1983), Tujuh Ratus Tahun Tuban, dan buku Hari Jadi Tuban (1987), Pemerintah Kabupaten Daerah Tingkat II Tuban. Laporan Ma Huan yang mengiringi Cheng Ho dalam pelayaran ke 3 (1413-1415), mencatat bahwa kalau orang Cina pergi ke Jawa, kapal-kapal lebih dulu sampai ke Tuban, baru kemudian meneruskan perjalanannya ke Gresik, kemudian dilanjutkan ke Surabaya, baru dari sana menuju ke pusat kerajaan Majapahit (di daerah sekitar 
Mojokerto sekarang) dengan memakai perahu kecil lewat sungai Brantas (Lombard, 2002 : 39). Begitu juga dalam penyatuan negeri-negeri Jawa oleh oleh senopati Mataram yang ingin memperkukuh kekuasaanya atas kota-kota pesisir. Tuban merupakan bagin yang tak terpisahkan dalam serangan-serangan dalam usaha penyatuan tersebut (Lombard, $2002: 36$ ).

Sebagaimana kedatangan Cheng Ho sebagai Laksamana dalam pelayaran yang sangat besar dalam ekspedisi militer dengan tujuan Jepang, Campa, Vietnam, dan Jawa dari tahun 1405-1453 menuju pelabuhan-pelabuhan Nusantara dan samudra Hindia, sampai ke Srilangka, Quilon, Kocin, Kalikut, Ormuz, Jeddah, mogodiscio dan Malindi. Dalam pelayaran tersebut Laksamana Cheng Ho pernah akan di rampok oleh Raja Perompak Cina ketika sampai di Palembang (Hall, 1988 : 88). Hal ini membuktikan bahwasanya minat pemerintahan raja-raja Ming pertama khususnya niat Kaisar Yongle terhadap perniagaan besar dan bagian yang tetap dipegang oleh kaum muslimin. Namun hal itu merupakan segi resmi dan menakjubkan dari penetrasi Cina yang sudah dimulai sejak lama dan berlanjutsecara diam-diam ((Lombard, 2002 : 30).

Pada awal abad ke 21 ini, tepatnya pada tgl. 24 Juli 2005, telah ditanda tangani pembangunan kilang minyak di Tuban oleh China Petrochemical Corporation, dengan Pertamina, untuk membangun kilang minyak berkapastas 150.000 -200.000 barel perhari. Jadi orang Cina datang lagi ke Tuban pada awal $21 \mathrm{ini}$.

\section{Jejak Sejarah Kota Tuban}

Kota Tuban terletak di Pantai Utara Jawa, antara dua kota besar, yaitu: Ibukota Propinsi Jawa Tengah (Semarang) dan Ibu Kota Propinsi Jawa Timur (Surabaya). Selain itu Tuban juga dilewati oleh jalan raya Daendels (dari Anyer 11 Kota lama Tuban dulunya terletak di daerah Semanding (sebelah Selatan kota Tuban sekarang). Bekas alun-alun lama kota Tuban yang terletak di desa Prungguhan Kulon Kecamatan Semanding. Penyerangan Mataram atas Tuban pada th. 1598 dan 1599 dapat digagalkan oleh Tuban (Graaf,1985:170). 
Kota Tuban memiliki asal usul dalam beberapa versi yaitu yang pertama disebut sebagai Tuban yang berarti watu tiban (batu yang jatuh dari langit) yaitu batu pusaka yang dibawa oleh sepasang burung dari Majapahit menuju Demak, dan ketika batu tersebut sampai di atas Kota Tuban, batu tersebut jatuh dan dinamakan Tuban. Adapun versi yang kedua yaitu berarti metu banyu berarti keluar air, yaitu peristiwa ketika Raden Dandang Wacana (Kyai Gede Papringan) atau Bupati Pertama Tuban yang membuka Hutan Papringan dan anehnya, ketika pembukaan hutan tersebut keluar air yang sangat deras. Hal ini juga berkaitan dengan adanya sumur tua yang dangkal tapi airnya melimpah, dan anehnya sumur tersebut dekat sekali dengan pantai tapi airnya sangat tawar. Ada juga versi ketiga yaitu Tuban berasal dari kata 'Tubo' atau Racun yang artinya sama dengan nama kecamatan di Tuban yaitu Jenu.

Nama Tuban berasal dari sebuah sumber air tawar yang ditemukan di tempat tersebut. Peristiwa ini membuat orang menamakannya " me (tu) (ban) yu " (keluar air). Sehingga tempat tersebut kemudian dinamakan Tuban. Dulunya Tuban bernama Kambang Putih. Sudah sejak abad ke-11 sampai 15 dalam beritaberita para penulis China (pada jaman dinasti Song Selatan 1127-1279 dan dinasti Yuan (Mongol) 1271-1368 sampai jaman dinasti Ming th.1368-1644 5), Letaknya sumber air bersih tersebut berjarak kurang lebih $10 \mathrm{~m}$ dekat pantai, tapi sumur (sumber air) tersebut tetap tawar dan segar.

Negara-negara baru di Indonesia yang menganut agama Islam bukan hanya menciptakan dinasti-dinasti dan kerajaan-kerajaan baru saja, tetapi sebuah warisan budaya yang beranekaragam. Beberapa diantaranya adalah warisan-warisan yang bersemangatkan Islam, tetapi sebagian besarnya mempunyai akar yang kuat pada kebudayaan pra-Islam juga. Memang tepat jika warisan ini dianggap klasik dalam arti bahwa warisan tersebut menetapkan norma-norma budaya otoritatif dan kerangka-kerangka makna bagi peradabab Indonesia sebelum abad XX (Ricklefs, 2005 : 116).

Masuknya Islam ke Nusantara dikalangan para ahli terjadi perbedaan pendapat. Ahmad Mansur Suryanegara mengikhtisarkannya menjadi tiga teori besar: Pertama, teori Gujarat. Islam dipercayai datang dari wilayah Gujarat - India 
melalui peran para pedagang India muslim pada sekitar abad ke-13 M. Kedua, teori Makkah. Islam dipercaya tiba di Indonesia langsung dari Timur Tengah melalui jasa para pedagang Arab muslim sekitar abad ke-7 M. Ketiga, teori Persia. Islam tiba di Indonesia melalui peran para pedagang asal Persia yang dalam perjalanannya singgah ke Gujarat sebelum ke Nusantara sekitar abad ke-13 M (Suryanegara, 2010 : 99).

Teori tersebut jika ditelaah lebih jauh sesungguhnya memiliki variasi pendapat yang cukup beragam. Terkait teori yang menyatakan bahwa Islam di Indonesia berasal dari anak benua India, misalnya, ternyata sejarawan tidak satu kata mengenai wilayah Gujarat. Pendapat Pijnappel yang juga disokong oleh C. Snouck Hurgronje, J.P. Moquette, E.O. Winstedt, B.J.O. Schrieke, dan lainlainnya tersebut ternyata berbeda dengan yang dikemukakan oleh S.Q. Fatimi dan G.E. Morison. Fatimi menyatakan bahwa bukti epigrafis berupa nisan yang dipercaya diimpor dari Cambay- Gujarat sebenarnya bentuk dan gayanya justru lebih mirip dengan nisan yang berasal dari Bengal. Sementara Morison lebih mempercayai bahwa Islam di Indonesia bermula dari pantai Coromandel. Sebab menurutnya, pada masa Islamisasi kerajaan Samudera dimana raja pertamanya (Malik al-Saleh) wafat tahun 1297 M, saat itu Gujarat masih merupakan kerajaan Hindu. Baru setahun kemudian, kekuasaan Islam menaklukkan Gujarat. Jika Islam berasal dari sana, tentunya Islam telah menjadi agama yang mapan dan berkembang di tempat itu. Adapun bukti epigrafis dari Gujarat atau Bengal, tidaklah serta merta menunjukkan bahwa agama Islam juga 'diimpor' dari tempat yang sama.

Sedangkan tentang teori Islam Indonesia berasal langsung dari Makkah (yang antara lain dikemukakan oleh T.W. Arnold dan Crawford) lebih didasarkan pada beberapa fakta tertulis dari beberapa pengembara Cina sekitar abad ke-7 M, dimana kala itu kekuatan Islam telah menjadi dominan dalam perdagangan BaratTimur, bahwa ternyata di pesisir pantai Sumatera telah ada komunitas muslim yang terdiri dari pedagang asal Arab yang di antaranya melakukan pernikahan dengan perempuan-perempuan lokal. Terdapat juga sebuah kitab 'Aja'ib al-Hind yang ditulis al-Ramhurmuzi sekitar tahun $1000 \mathrm{M}$, dikatakan bahwa para 
pedagang muslim telah banyak berkunjung kala itu ke kerajaan Sriwijaya. Dan di wilayah itupun telah tumbuh komunitas muslim lokal. Sementara variasi pendapat lain dikemukakan oleh Keijzer bahwa Islam nusantara berasal dari Mesir berdasar kesamaan madzhab (Shafi'i). Sedangkan Niemann dan de Hollander mengemukakan teori Islam nusantara berasal dari Hadramaut (wilayah Yaman).

Teori Persia yang dikemukakan oleh sebagian sejarawan di Indonesia tampaknya kurang populer dibanding teori-teori sebelumnya. Pada konteks ini menarik jika pendapat Naguib al-Attas, seorang pendukung teori Arab, dihadirkan sebagai komparasi. Dalam mengkaji Islam nusantara, al-Attas lebih tertarik untuk mendasarkan argumentasinya pada bukti-bukti konseptual dan literatur, dibanding bukti-bukti epigrafis sebagaimana para pemikir sebelumnya. Dalam "teori umum tentang Islamisasi nusantara"-nya tersebut al-Attas menyebutkan bahwa karakteristik internal Islam di nusantara lebih cenderung berasal langsung dari Arab. Dari berbagai literatur Islam yang beredar di nusantara sebelum abad ke-17 M, tak satupun pengarangnya adalah orang India. Bahkan sebagian penulis yang dipercayai beberapa sarjana Barat sebagai berasal dari India atau Persia, jika ditelisik ternyata berasal dari Arab baik etnis maupun kultural. Adapun mengenai bukti epigrafis Moquette, al-Attas menolaknya, dan menyatakan bahwa kemunculan nisan-nisan dari India tersebut hanya karena faktor kedekatan lokasi saja (dalam konteks perdagangan).

Selanjutnya tentang proses Islamisasi di Nusantara, menarik untuk diperhatikan beberapa pendapat berikut: Pertama, teori perkawinan. Terdapat pendapat yang menyatakan bahwa kesuksesan Islamisasi di Nusantara lebih karena peran para pedagang muslim. Di gambarkan, bahwa seraya berdagang mereka juga menyebarkan Islam. Di antaranya dengan cara melakukan perkawinan dengan perempuan lokal sehingga terjadi konversi agama dan terbentuklah lokus-lokus komunitas muslim setempat. Selanjutnya, mereka juga berusaha menikahi perempuan bangsawan dengan harapan anak keturunannya akan beroleh kekuasaan politik yang dapat dipakai untuk menyebarkan agama Islam. Segaris dengan pemikiran ini, J.C. van Leur mengemukakan adanya motif ekonomi dan politik dalam persoalan konversi penduduk atau penguasa lokal di 
nusantara. Menurutnya, penguasa pribumi yang ingin masuk dan berkembang dalam perdagangan internasional kala itu yang terbentang dari Laut Merah hingga Laut Cina akan cenderung menerima Islam karena dominasi kekuatan muslim di sektor itu. Di samping pula untuk membentengi diri dari jejaring kekuasaan Majapahit.

Teori ini dikritik oleh A.H. Johns, yang menurutnya, patut diragukan bahwa para pedagang akan mampu meng-Islam-kan penduduk lokal dalam jumlah yang signifikan. Bukankah ditengarai bahwa mereka telah hadir sejak abad ke-7 atau ke-8 M di nusantara, tetapi nyatanya, Islamisasi yang signifikan justru tampil di sekitar abad ke-12 M. Johns lalu mengajukan teori Sufi-nya. Menurutnya, Islamisasi di nusantara sukses lebih didorong oleh peran para sufi pengembara yang memang orientasi hidupnya diabdikan untuk penyebaran agama Islam. Dan pada masa-masa massifikasi konversi Islam itulah para sufi banyak hadir di nusantara. Johns dalam mengelaborasi teorinya juga mengambil pemikiran tentang cara perkawinan dengan keturunan penguasa lokal sebagai pendukung proses Islamisasi. Adapun pendapat lain yang dikemukakan oleh Schrieke bahwa faktor pendorong yang menimbulkan gelombang besar masuk Islam di nusantara adalah ancaman kekuasaan kolonial dan misi gospel Kristen yang agresif tampaknya sulit diterima, karena dalam sejarah tercatat bahwa bangsa Barat Kristen tiba di nusantara baru sekitar tahun 1500-an. Sementara Islamisasi di nusantara telah berlangsung secara signifikan jauh sebelumnya yakni sejak abad ke-12atauke-13M.

Dikemukakan oleh Azyumardi Azra berikut ini: "Pertama, Islam dibawa langsung dari Arabia; kedua, Islam diperkenalkan oleh para guru dan penyiar "professional" - yakni mereka yang memang secara khusus bermaksud menyebarkan Islam; ketiga, yang mula-mula masuk Islam adalah para penguasa; dan keempat, kebanyakan para penyebar Islam "professional" ini datang ke Nusantara pada abad ke-12 dan ke-13." Jadi dengan mempertimbangkan berbagai uraian di atas, dapat dinyatakan bahwa mungkin benar Islam memang telah diperkenalkan awal mula sejak abad-abad pertama Hijriyah (sekitar abad ke-7 M), 
namun akselerasi persebaran Islam secara nyata baru terjadi sekitar abad ke-12 M dan masa-masa selanjutnya.

Menurut hemat saya, masuknya Islam ke Nusantara sampai sekarang masih misterius dan kabur (Woodward, 1999 : 80), siapa nama penyebar agama Islam serta kapan penyebaran (da'wah) itu belum bisa dijawab secara tuntas. Sekalipun begitu proses penyebaran Islam di Nusantara secara damai dengan daya survival sebagai pedagang hampir semua peneliti menyepakatinya. Sekalipun begitu, menurut hemat saya, para peneliti telah tertipu dengan proses Islamisasi yang dilakukan oleh para saudagar dan sitem perkawinan dengan pribumi. Hal ini hanya bisa dilihat dari proses penyebaran Islam ke negara-negara lain, misalnya Eropa, Timur Tengah dan India.

Hal ini juga ditegaskan dalam sebuah buku yang berjudul " Panggung Sejarah". dalam buku tersebut dijelaskan bahwasanya unsur-unsur budaya Islam di Indonesia, sejak masa pertama kali datang, tumbuh dan selanjutnya berkembang sejalan dengan pelembagaan agama Islam, dapat dilihat lebih sebagai proses sejarah daripada sebagai pristiwa sejarah. Hal tersebut disebabkan, antara lain, Islam masuk ke Indonesia bukan seketika, demikian asal dan tempat masuknya juga tidak sama di berbagai lokalitas Nusantara (Ambari, Loir. 1999 : 206).

Kedatangan Islam di wilayah-wilayah tersebut tidak dengan jalan damai, yakni dengan pasukan perang. Sebagai konsekwensinya para penyebar agama Islam tersebut mendapatkan ghnimah (harta rampasan perang termasuk budak perempuan) dan hal itu dibolehkan dalam ajaran Islam. Sedangkan para peneliti cenderung melupakan hal tersebut, sehingga kesan uraiannya tentang para penyebar Islam di Nusanatara dikonotasikan sebagai pedagang yang sambil berda'wah.

Para penyebar Islam yang datang ke Indonesia tidak mendapatkan fasilitas ghanimah seperti halnya; Qosim di India, Kholid bin Walid di Mesir, dll. Para shahabat Nabi yang berda'wah ke Indonesia adalah murni berda'wah seperti yang diajarkan Nabi mereka. Oleh karena mereka tidak mendapatkan fasilitas ghanimah (harta rampasan perang) sedangkan mereka harus tetap hidup untuk 
menjalankan misinya, maka sesuai dengan alam kebudayaan Arab, mereka hanya bisa berdagang, mereka tidak bisa bertani. Oleh karena aktifitas perdagangan para sahabat ini hanya sekedar untuk bertahan hidup bukan memperkaya diri. Jika benar asumsi yang dibangun oleh para peneliti bahwa para saudagar yang menyebarkan agama Islam di Nusantara, harusnya kaum muslim adalah kelompok menengah (pedagang, bukan petani). Akan tetapi, fakta lapangan yang sampai kini bisa dijumpai bahwa penganut agama Islam tersebut adalah kelompok kaum tani.

Dengan begitu, kemudian ada benang merah antara kekhasan Islam sufistik (non materi) yang banyak dianut oleh masyarakat Indonesia, khususnya Jawa, dengan proses persebaran Islam pada awal mulanya, termasuk di Tuban. Ekspansi Islamisasi ini kemungkinan terjadi jauh sebelum periode dewan wali songo. Menurut cerita tutur, penyebaran ini terjadi pada masa khalifah ke-2 Bani Ummayah, yakni khalifah Yazid bin Muawwiyah di Mesir. Lembaga dewan da'wah yang bernama wali songo (semacam MUI dalam era sekarang) bukanlah penyebar agama Islam pertama di Jawa sekalipun mereka adalah peletak konseptual proses persebaran Islam selanjutnya. Dewan wali songo ini dapat berdiri setelah komunitas muslim terbentuk serta para pendahulu mereka dapat mempengaruhi kerajaan majapahit, sehingga nyaris tidak terjadi pergolakan yang berarti pada kala itu. Akan tetapi, proses islamisasi secara konseptual dan sitematis terjadi pada era mereka, sehingga membincangkan mereka menjadi signifikan.

Tuban pada saat itu tidak hanya menjadi tempat penting pada masa Kerajaan Majapahit, namun Tuban juga menjadi tempat penting pada masa penyebaran Agama Islam. Hal tersebut dikarenakan Tuban berada di pesisir Utara Jawa yang menjadi pusat Perdagangan Arab yang sedang menyebarkan Agama Islam. Hal ini juga berkaitan dengan kisah Sunan Bonang dan Sunan Kalijaga. Sunan Kalijaga adalah putra dari Bupati Tuban VIII Raden Tumenggung Haryo Wilwotikto. Sunan Kalijaga dikenal sebagai Brandal Loka Jaya, karena sebelum jadi Wali, Sunan Kalijaga adalah brandal (preman) yang suka mencuri hasil kekayaan Kadipaten Tuban. Namun, hasil curian tersebut dibagikan para fakir miskin. Lama-kelamaan, perbuatan tersebut diketahui oleh ayahanda Sunan 
Kalijaga dan diusir dari Kadipaten Tuban. Raden Syahid tidak boleh kembali sebelum mampu menggetarakan Kabupaten Tuban dengan ayat-ayat suci alQur'an. Dalam pengasingannya, Raden Syahid bertemu dengan Sunan Bonang.

Sunan Bonang memiliki Tongkat emas yang membuat Raden Syahid menjadi ingin memiliki tongkat tersebut. Sesaat kemudian, Sunan Kalijaga merebut tongkat emas dan Sunan Bonang jatuh tersungkur. Sunan Bonang menangis dan Sunan Kalijaga merasa iba. Akhirnya Sunan Kalijaga mengembalikan Tongkat Sunan Bonang dan Sunan Kalijaga bertanya bagian mana yang membuat beliau kesakitan. Namun, Sunan Bonang menangis bukan karena kesakitan, tapi beliau menangis karena memutuskan rumput dan beliau berkata bahwa beliau merasa kasihan karena rumput yang tidak bersalah harus mati tercabut karena kesalahan beliau. Sesaat kemudian, beliau menancapkan Tongkat di Pesisir dan menyemburkan air. Tempat tersebut dinamai Sumur Srumbung. Setelah itu, Sunan Bonang menunjukkan Buah Aren yang berwarna emas. Raden Syahidpun tergoda dan memanjat pohon aren tersebut, tapi sebuah aren menimpa kepala beliau dan beliaupun pingsan. Setelah sadar, Raden Syahid diajak Sunan Bonang menuju Sungai di daerah Sekardadi Kecamatan Jenu. Di sana, beliau menjaga tongkat Sunan Bonang yang ditancapkan pada sebuah batu. Anehnya, beliau tertidur selama 2 tahun. setelah sadar, Raden Syahid diberi pakaian dhalang oleh Sunan Bonang dan diJuluki Sunan Kalijaga, maksudnya Kali dalam bahasa Indonesia berarti sungai, dan Jaga dimaksudkan karena sudah menjaga tongkat Sunan Bonang. Namun kebenaran cerita ini belum memiliki bukti bahwasanya sebutan Sunan Kalijaga di karenakan menjaga tongkat Sunan Bonang di pinggir sungi.

Secara filosofis penamaan Sunan Kalijaga dinisbatkan pada bentuk penjagaan peradaban Nusantara. Peranan sungai pada saat itu memiliki fungsi yang signifikan sebagai sarana transformasi menuju pedalaman. Baik menuju Kerajaan Majapahit atau kerajaan Singosari. Sarana transportasi tidak hanya menggunakan jalur darat akan tetapi juga melalui sarana sungai. Kedalaman sungai-sungai di Jawa menjadi sarana dalam menyebarkan kebudayaan ke pulau Jawa. Kapal-kapal bisa berlayar dengan leluasa tanpa mengalami hambatan 
kedangkalan sungai. Hal ini menjadikan pemikiran, bagaimana manjaga agar peradaban Nusantara tidak tergerus oleh kebudayaan Barat melalu transportasi sungai. Hemat penulis makna Kalijaga merupakan penjagaan terhadap peradaban yang sudah mengakar pada diri masyarakat Jawa. Oleh karena itu, Sunan Kalijaga dengan ihtiar kebudayaan yang telah mengakar dalam kehidupan masyarakat Jawa memiliki tugas menjaga kebudayaan tersebut agar tidak tercerabut dari akarnya yang disebabkan arus perkembangan zaman atau globalisasi.

\section{E. Penutup}

Tuban sebagai bagian sejarah dalam pergulatan panjang penyebaran Islam yang memiliki peranan penting dalam penyebaran Islam ke Nusantara tidaklah bisa dielakan lagi. Hal ini dikarenakan peranan Bandar atau dermaga besar yang dimiliki oleh Tuban menjadi pelabuhan bagi para pelaut. Pedagang, penyebar agama. Begitu juga dengan alun-alun sebagai identitas kota Tuban sangat penting. Selain berperan sebagai landmark, bangunan disekelilingnya yang berperan sebagai elemen pembentuk ruang kota, bisa menggambarkan perjalanan sejarah kotanya di masa lampau. Pengaruh kerajaan kuno Hindu Jawa bisa dilihat dari kehadiran alun-alun serta kantor Kabupatennya. Pengaruh jaringan perdagangan Asia bisa dilihat dari bangunan kelenteng, pasar dan Pecinan yang terletak di depan alun-alun. Pengaruh masuknya agama Islam bisa dilihat dari adanya mesjid raya serta makam Sunan Bonang. Pengaruh warisan birokrasi Kolonial bisa dilihat pada gedung pengadilan, gereja, kantor pos dan penjaranya. Jadi, Nusa Jawa sebagai silang budaya bisa tercermin pada alun-alun dan bangunan sekelilingnya di kota Tuban. Pada abad ke 21 kota Tuban merevitalisasi alun-alun, tempat ibadah serta bangunan pemerintahan disekitarnya sebagai pusat dan bagian dari pembangunan jati diri kotanya. Apakah usaha revitalisasi tersebut, merupakan contoh dari kebangkitan kembali atau semacam renaissance alun-alun sebagai pusat kota bagi kota-kota Kabupaten di Jawa yang sudah lama kehilangan jati dirinya ?

Dalam hal keanekaragaman agama dan budaya. Toleransi dan penghormatan terhadap perbedaan sangatlah terlihat. Hal ini ini dapatlah dilihat dalam bangunan peribadatan yang satu jalur dan saling berdekatan baik itu Masjid 
Agung, Klenteng maupun Gereja. Namun, walau demikian saling menghormati dan menghargai selalu dihadirkan dalam kehidupan sehari-hari warga Tuban.

Apalagi dengan keberadaan agama Islam yang memberikan kedamaian dalam kehidupan sehari-hari tanpa harus mempersoalkan keyakian orang lain. Kita ketahui sebelum Islam masuk keyakinan masyarakat local adalah HinduBudha. Akan tetapi mereka senantiasa membuka diri akan adanya perbedaan.

\section{DAFTAR PUSTAKA}

Brown dikutip pada Religion and Society (dalam Journal of The Royal Anthropological Institue, vol. LXXV). Yogyakarta: Tiara Wacana

Colombijn, Freek. 1994. Paco-Paco (Kota) Padang. Sejarah Sebuah Kota di Indonesia pada Abad Kedua Puluh dan Penggunaan Ruang Kota. Padang: Dinas Pariwisata dan Kebudayaan Kota Padang dengan Badan Warisan Sumatera Barat

Daldjoeni, N.. 1998. Geografi Kota dan Desa. Bandung: Penerbit Alumni.

Durkheim, Emile. 1995. Elementary Forms of Religious Life (edisi 1964), hlm. 47, dikutip dalam Betty R. Scharf, Kajian Sosiologi Agama. Yogyakarta: Tiara Wacana.

Freek Colombijn. 2004. "Urban Symbolism in Indonesian History", dalam "Workshop: Street Image: Decolonization and Changing Symbolism of Indonesian Urban Culture, 1930-1960s" (diselenggarakan oleh PSSATUGM bekerjasama dengan NIOD, Yogyakarta: 27 Agustus-11 September 2004).

Hall, D.G.E.. 1988. Sejarah Asia Tenggara. Surabaya: Usaha Nasional.

Hari Jadi Tuban, Pemerintah Kabupaten Daerah Tingkat II Tuban. 1987.

Kartodirdjo, Sartono. 1977. Masyarakat Kuno dan Kelompok-kelompok Sosial. Jakarta: Bhratara Karya Aksara.

Koentjaraningrat. 2007. Sejarah Teori Antropologi I, II. Jakarta: UI-Press.

Kuntowijoyo. 1998. Agama dan Kohesi Sosial. Buletin Fakultas Sastra UGM, No. 9, Nov-Des, hlm. 2. Yogyakarta: Humaniora 
Lombard, Denys. 2002. Nusa Jawa: Silang Budaya Jilid I,II,III. Jakarta: PT. Gramedia Pustaka Utama.

Loir, Henry Chambert. Edt. Hasan Muarif Ambari. 1999. Panggung Sejarah, Persembahan kepada Prof. Dr. Denys Lombard. Jakarta: Yayasan Obor Indonesia

Putra, Heddy Shri Ahimsa. 2009. Strukturalisme Levi-Strauss Mitos dan Karya Sastra. Yogyakarta: Kepel Press.

2002. Tanda, Simbol, Budaya, dan Ilmu Budaya. Yogyakarta: Makalah dalam Ceramah Kebudayaan di Fakultas Sastra Ilmu Budaya, UGM, 13 Juni 2002).

Rahardjo. 1981. Perkembangan Kota dan Beberapa Permasalahannya. Yogyakarta: Fakultas Sosial dan Politik Universitas Gadjah Mada.

Ricklefs, M.C. 2005. Sejarah Indonesia Modern 1200-2004. Jakarta: PT Serambi Ilmu Semesta.

R., Soeparmo. 1983. Tujuh Ratus Tahun Tuban. tk:tp.

Santoso., Jo, Suryadi. 1984. Bentuk Kota Di Jawa Sampai Dari Abad Ke XVIII. tk:tp.

Scharf, Betty R.. 1945. Kajian Sosiologi Agama. Pendapat A. Radcliffe-.

Suryanegara, Mansur, Ahmad. 2010. Api Sejarah. Bandung : Salmadani.

Suryo, Djoko. 2004. Sejarah Perkotaan di Indonesia: Dari Kota Tradisional sampai Kota Kolonial. Makalah pada "Workshop: Street Image: Decolonization and Changing Symbolism of Indonesian Urban Culture, 1930-1960s" (diselenggarakan oleh PSSAT-UGM bekerjasama dengan NIOD, Yogyakarta: 27 Agustus-11 September 2004).

Timur Pada Abad ke 16: Tuban, hal. 163-171. dan Bab XXI: Sebab-Sebab Kekalahan Kerajaan Jawa Timur Dan Pesisir Dalam Perang Melawan Mataram Pada Abad ke 16 dan 17, 1985, hal. 297-304. Graaf, H.J. De, Cina Muslim di Jawa Abad XV dan XVI antara Historisitas dan Mitos, terjemahan dari Chinese Muslims in Java in the 15th and 16th centuries: The Malay Annals of Semarang and Cirebon, PT Tiara Wacana, Yogya. 1998.

Toer, Pramoedya Ananta. 2002. Arus Balik, Sebuah Epos Pasca Kejayaan Nusantara di awal abad 16. Jakarta: Hasta Mitra. 
Wiryomartono, A. Bagoes P.. 1995. Seni Bangunan dan Seni Binakota di Indonesia. Kajian mengenai Konsep, Struktur, dan Elemen Fisik Kota sejak Peradaban Hindu Budha, Islam hingga Sekarang. Jakarta: Gramedia Pustaka Utama.

Weber, Max. 1964. The Sociology of Religion. Boston: Beacon Press. Terjemahan Ephraim Fischof.

Woodward, Mark R.. 1999. Islam Jawa, Kesalehan Normatif Versus Kebatinan. Yogyakarta: LKiS. 